\title{
Cultural Diversity in the News Media: A Democratic or a Commercial Need?
}

Isabel Awad-Cherit (awad@eshcc.eur.nl)

\begin{abstract}
This paper distinguishes between laissez-faire and interventionist models used to justify and implement cultural diversity initiatives in the news media. The laissez-faire model is characteristic of U.S journalism. However, due to the convergence of media systems and the widespread adoption of diversity management, the laissez-fair model may also become the prevalent model throughout other Western democracies, in Europe and elsewhere. The paper argues that the problem with the laissez-fair approach to cultural diversity in the media is that it relies on commercial instead of normative justifications. As a result, cultural diversity is mostly reduced to ornament. Equated with accuracy and treated as a business asset, diversity serves, rather than challenges, the existing media system. By failing to open sufficient spaces for alternative social voices, business-driven media policies do not respond to the democratic needs of a multicultural society.
\end{abstract}

\section{Full reference:}

Awad, I. (2008). Cultural diversity in the news media: A democratic or a commercial need? Javnost-The public, 16 (4), pp. 55-72. 


\title{
Cultural Diversity in the News Media: A Democratic or a Commercial Need?
}

\author{
Isabel Awad-Cherit
}

\section{Introduction}

As discussions about multiculturalism have gained importance throughout Europe, North America and other parts of the world, cultural diversity has become a major concern also for journalism. News media are increasingly expected to recognize multiple ethnic constituencies and to take measures to represent these constituencies more strongly in the news agenda, the newsroom's workforce, and the audience. Common among these measures are initiatives to recruit more minority media professionals; to train reporters to be more sensitive to cultural differences; and to produce special programs or publications targeting minority audiences.

Whereas calls to bring cultural diversity into the news media can be heard across national contexts, they are not always justified and implemented in the same way. Following Stratton and Ang (1994), I distinguish between "laissez-faire" and "interventionist" ways to deal with cultural diversity. The laissez-faire model can be identified with the United States, where the state plays only a marginal role in the promotion and enforcement of multicultural policies. "[I]mmigrants are left to themselves to find a place in the new society, under the assumption that they will be quickly absorbed into and by the established cultural order" (Stratton \& Ang 1994, 128). This assumption also involves immigrants' absorption into the established economic order. Thus, in the United States the relationship between news media and cultural diversity is discussed as a normative ideal and as a business asset. Diversity is promoted as a source of journalistic excellence and as a source of economic profit. As a source of journalistic excellence, diversity is a condition for the media's fulfillment of their social responsibility. As a source of profit, it is a condition for media's survival in the marketplace.

The interventionist model, in contrast, underlies governmental efforts to distribute economic resources, ensure legal regulations, and engage openly in public discourse to promote certain multicultural goals. In this way, diversity remains largely contained within broader normative discussions about democratic participation and social inclusion. In the case of media diversity, interventionism justifies policies to secure minorities' media access and representation. Press subsidies for minority media and the allocation of public television and radio airtime for multicultural programming are among the policies with which the state can promote cultural diversity in the media beyond the diversity that may result from the dynamics of the marketplace.

This paper argues that interventionist policies to bring cultural diversity into the media are endangered. As a result, the laissez-faire approach may become the only way to deal with media diversity in Western multicultural democracies and, specifically, in Europe. Two broader trends point in this direction. On the one hand, there is a well documented tendency towards convergence in media systems (e.g., Hallin \& Mancini 2004; Iosifides 1999; Sinue \& McQuail 1986; Van Cuilenburg \& McQuail 2003). On the other hand, North American practices to "manage diversity" are gaining importance in European organizations (Lorbirecki 2001; Wrench 2005) and are being promoted at the highest levels of European policy (e.g., Brussels Debate Highlights... 2008; Centre for Strategy and 
Evaluation Services 2003; Making Progress in 2007 2007). Both trends make a critical analysis of the U.S. journalism's approach to cultural diversity particularly relevant and timely for cross-national discussions about the media and multiculturalism.

The paper starts with an overview of the forces that make the laissez-faire approach to media diversity prevail over the interventionist model. Specifically, this overview focuses on recent changes in European policies in relation to the media and to cultural diversity. Subsequently, the paper outlines the defining features of the U.S. media system and observes important limitations in its capacity to foster diversity. The central problem has to do with how U.S. journalism's outspoken commitment to cultural diversity has been accommodated within a homogenizing and hegemonic media system. The paper argues that business, rather than democratic imperatives, have shaped the way in which U.S. journalism defines and implements cultural diversity. As a result, the news media have failed to open sufficient spaces for alternative social voices. In that sense, the media have not fulfilled their democratic role in a multicultural society. The discussion finally argues that those who advocate for media diversity should be attentive to the dangers of letting economic arguments prevail over normative ones.

\section{The Reshaping of Media Diversity Policy}

In their comparative analysis of media systems in Western Europe and North America, Hallin and Mancini (2004) distinguish between democratic corporatist, polarized pluralist, and liberal media systems. They describe the U.S. media system as "clearly the purest form of the Liberal Model" (2004, 228), characterized by a significant mass circulation and profitable press; a relative disconnection between the media and political parties; a highly professionalized workforce; and a low level of state intervention. The resulting relationship between media and politics in the U.S. contrasts with the situation in most European countries. The contrast is particularly strong between the U.S. and countries that have a polarized pluralist media system, such as France, Italy, and Spain. Not as strongly, but still significantly, the U.S. system differs from the democratic corporatist model found in North and Central European countries, including The Netherlands, Germany, and Sweden. Countries with polarized pluralist and with democratic corporatist media systems present significant ties between the media and political parties. As a result, audiences are segmented along political lines. Likewise, in most European countries public media, press subsidies, and other kinds of state intervention play an important role, while journalists are not always as autonomous from political parties and other special constituencies as in the United States.

Although Hallin and Mancini (2004) recognize important distinctions in media systems across the different countries they examine, they also underscore how current trends toward convergence weaken those distinctions. This is a phenomenon widely recognized by media scholars. Already in the mid-1980 Siune and McQuail $(1986,1)$, for instance, argued that "the spirit in which many [European media] policy areas are approached can be summed up by the term 'deregulation', imported to Europe from the USA." More recently, Brants and Praag $(2006,25)$ have predicted that "sooner or later, the modes and styles of American media will appear in Europe too." Typically, these changes in the European media landscape are discussed in terms of "privatization, internationalization, commercialization, and media concentration" (Siune 1998, 1). These developments affect diversity in the media to such an extent that diversity in general - not only cultural diversity, but also political, regional, linguistic, and other forms of diversity- 
"is said to be the most vulnerable value at stake in the concentrated and deregulated European media industry" (Iosifides 1999, 154).

The second phenomenon affecting media diversity in Europe is more recent and not specific to the media. It affects all kinds of corporations, which have embraced diversity as a management tool, among other things, to improve their reputation; generate more creative and productive working environments; and expand their market share. Known as "diversity management," this approach to cultural diversity was developed in the United States in the 1980s and has become "a relatively normal business practice, at least among the bigger corporations" (Wrench 2005, 74). According to Roosevelt Thomas, the founder of the American Institute for Managing Diversity and a leading expert in the field, diversity management is "a new way of thinking about diversity, not as an 'us/them' kind of problem to be solved but as a resource to be managed" $(1991,10)$. In Thomas's view, corporations should replace the traditional notion of diversity, which focuses on civil rights, women's rights, humanitarianism, moral and human responsibility, with the "managerial" perspective in which "managers place priority on the interests of their corporations" (1991, 17).

Lately, diversity management has also become common practice in European companies (Lorbiecki 2001; Wrench 2005). Moreover, the "business case for diversity" has been advanced by European agencies that aim at fighting discrimination and at promoting cultural diversity. As a 2003 report for the European Commission explains, Evidence has begun to emerge that a number of leading companies, and some small and medium-sized enterprises (SMEs), have set up diversity policies for business reasons i.e. to create improved wealth and to strengthen competitive advantage. The reputation of some of the businesses involved and the growing scale of the activity, suggests that there exists a "business case" to justify the investment of resources in the establishment of diversity policies. Identification of this "business case", and its dissemination to companies through public sector action could help to stimulate wider use of diversity policies by the corporate sector (Centre for Strategy and Evaluation Services 2003, 2).

In line with this view, the dissemination of the so-called business case became an important priority in the European Commission's campaign against discrimination in 2007 (Making Progress in 2007 2007). It was also promoted in the context of the European Year of Intercultural Dialogue 2008 (Brussels Debate Highlights... 2008).

At both sides of the Atlantic, diversity management seems as suitable for the media as for other types of organizations. In the United States, large news corporations- such as National Public Radio (NPR), The New York Times, the Tribune Corporation, and Gannett - have management teams in charge of diversity issues. Likewise, agencies specifically dedicated to the promotion of media diversity rely on business arguments. An example is the Robert C. Maynard Institute for Journalism Education, one of the most prominent institutions promoting cultural diversity in U.S. journalism. The institute's website has a section on diversity management, which includes a list of recommended readings as well tips to recruit minority employees.

Though relatively new, the business case for diversity in the media has already gained significant recognition in Europe. It can be observed, for example, in some of the most recent diversity efforts of the European Broadcasting Union (EBU). One of them is the EBU's Diversity Toolkit. Aimed at journalists and media producers, the toolkit was 
published in 2007 by the European Agency for Fundamental Rights. It consists of a DVD with news clips broadcasted by public television networks from different European countries, and an instruction booklet, which includes a chapter on "Managing Diversity." According to the booklet, "[p]ublic service broadcasters should reflect the audience they serve, if they are to remain relevant and viable in an increasingly globalised world. This makes business sense and aids social cohesion" (A Diversity Toolkit 2008, 49). Similarly, the EBU stressed the business case for diversity in its third European conference on media and intercultural dialogue. The conference was organized in 2008 by the Dutch public broadcasting organization. It was sponsored by the EBU in collaboration with public broadcasters from Germany, France, the Netherlands, the UK, and Belgium. Entitled "The Diversity Show," the event was promoted as "an inspiring international meeting and workshop for everybody within the media industry who regards cultural diversity not only as a fact of life, but as a creative opportunity" (EBU 2008). Two of the keynote speakers were: U.S. marketing consultant and bestselling author Stedman Graham and EBU president, Fritz Pleitgen. Graham-whose books include Build your own life brand!; You can make it happen; and Diversity: Leaders, not Labels-would talk about "[d]iversity as a permanent business characteristic in the global environment" (The Diversity Show 2008b). Pleitgen, in turn, would specifically focus on European media companies' "track record on managing diversity," according to the preliminary program (The Diversity Show 2008a).

\section{U.S. Journalism and its Incompatibilities with Cultural Diversity}

What are the democratic implications of the growing supremacy of the laissez-faire model of multiculturalism for the news media? In order to answer this question, this section focuses on the basic features of U.S. journalism and on how these features affect cultural diversity. While U.S. journalism is outspoken in its commitment to cultural diversity, it is important to examine what this diversity means and how it is put into practice.

As mentioned above, two defining characteristics of the liberal media system are commercialization and low political parallelism (i.e., the fact that the media and political parties are relatively disconnected). In the United States, both characteristics have been closely related to each other. The early and intense expansion of mass-circulation publications since the 1830 s and throughout the $19^{\text {th }}$ century quickly marginalized noncommercial media and "transformed the political role of the press" (Hallin \& Mancini 2004, 203). This transformation implied a move away from open political partisanship and economic reliance on political parties and wealthy politicians towards both political and economic independence. In this way, commercialization helped neutralize the press's political content and contributed to its lack of political parallelism. Instead of the diversity that may result from a range of diverse media outlets, the U.S. media system has traditionally privileged "internal pluralism." This means that "media organizations both avoid institutional ties to political groups and attempt to maintain neutrality and 'balance' in their content" (Hallin \& Mancini 2004, 29).

Because of its roots in commercialization, internal pluralism does not only refer to strictly political issues. It also characterizes the U.S. media system more generally. Examining radio formats in various markets, Glasser $(1984,129)$ for example, argues that "format duplication is the rule, not the exception." Thus, the most profitable format is rarely "underrepresented" in the market. "Inevitably, when consumer welfare is defined economically, instead of culturally, variety will be mistaken for diversity" (Glasser 1984, 140). In Glasser's conceptualization, variety stands for superficial and idiosyncratic 
differences, while diversity refers to differences related to "the purposes and interests common to a class of people" (p. 140).

A "reduced product differentiation" is an inevitable consequence of the market dynamics of advertising-based media (Baker 2002, 27) and complicates these media's alleged political neutrality. Since there is a double transaction going on-audiences purchase media products and advertisers purchase those audiences - media production is shaped by the interests of both advertisers and audiences. However, in the negotiation between these two categories of interests, audiences end up being served insufficiently and inequitably. "[P]ossibly advertisers' most important impact on media is to increase the prevalence of media content relevant to their favored audiences" (Baker 2002, 26). This means that although the U.S. media's political orientation may be rather undifferentiated, it does exist. "They [the media] all have essentially the same orientation-a centrist one ... as well as one oriented toward the views of the white-middle class readers who are the preferred target of advertisers" (Hallin \& Mancini 2004, 210). Moreover, this suggests that political "neutrality" actually operates hegemonically by privileging dominant interests over the interests of disempowered social groups. Advertisers' target market ends up having a relatively homogeneous profile: middle and high socio-economical classes are served at the expense of poorer segments of the population.

Although this has been the prevalent case in the United States, commercialization does not necessarily oppose political parallelism. "Under the right political and economic conditions, opinion sells," explain Hallin and Mancini $(2004,286)$. This would account for recent "countertrends" in the U.S. media system, including the rise in popularity of openly partisan radio and cable television programs. In the last years, Republican and Democratic views have become sharply distinguishable in the U.S. news, according to the Pew Research Center's The State of the News Media report (Ruby \& Project for Excellence in Journalism 2008). However, the diversity of political views that actually find space in the mainstream media is limited. First, partisanship seems to be more or less constrained to the Republican-Democratic spectrum. Second, "the partisan divide" is visible in relation to a limited number of topics. According to the Pew Research Center's report, in 2007, partisanship was evident in stories about the war in Iraq, but not in the coverage of the presidential election. "Nearly everyone tended to think there was too much early handicapping of the race, too little coverage of so-called minor candidates and too little coverage of what the candidates were saying" (Ruby \& Project for Excellence in Journalism 2008). Even when opening spaces for more opinionated media then, commercialization may impose important ideological constraints.

The professional communicator. Media commercialization in the United States, it was mentioned above, has historically been tied to the neutralization and the homogenization of media content. Another factor contributing to the relatively narrow and non-partisan news content in liberal media systems is journalists' high degree of professionalism. As Carey (1969) has explained in relation to the emergence of "the professional communicator" in the late $19^{\text {th }}$ century United States, "Originally the development of this form of journalism was grounded in a purely commercial motive: the need of the mass newspaper to serve politically heterogeneous audiences without alienating any significant segment of the audience" (p. 32). The commercial motive was thus a necessary condition for the rise of objectivity as the dominant "ideology" of U.S. professional journalism (Carey 1969; Glasser 1992a; Hallin 1985). Not only did commercialization favor political neutrality, but it also demanded higher levels of 
efficiency in news production. Journalists' professionalism, in short, cannot be understood outside the politico-economic model in which it exists.

The professional communicator described by Carey (1969) replaced the "independent interpreter of events" by leaving aside "advocacy and criticism" and adopting a series of standardized techniques (pp. 32-33). Instead of independently interpreting the world around them, journalists thus became objective transmitters of facts of which they allegedly have no control. The techniques to ensure objectivity, extensively documented in the research on news production in the United States, underscore both the uniformity of professional news making and its political detachment (see, for example; Gans 1980; Soloski 1989; Tuchman 1978). The result, argues Fishman (1980, 17), is "a uniform view of the world which can only be characterized as ideological."

The ideology of objectivity operates at basically two levels. First, journalists take objectivity and its routines for granted, as the natural way in which news is "gathered" rather than produced (Glasser 1992a). Secondly, the news journalists produce is assumed to be a neutral product, one which treats all social interests equally. According to the ideology of objectivity, journalists can and must free themselves from all "biases" tied to personal, political, or other interests in order to serve the supposedly superior and perfectly impartial "public interest," commonly translated into "the public's right to know." As a result, apparent biases in media coverage are seen as unprofessional. ${ }^{2}$ Similarly, major flaws in news making are routinely translated into a lack of objectivity. This is, for example, how the 2008 report on The State of the News Media refers to the proliferation of unreliable online sources. Based on a survey with newspaper editors, the report concludes: "In a world where much of the new, fast-proliferating information available to the consumer stems from Internet sources that undergo little or no quality control, guarding the newspaper's objectivity and credibility is considered crucial" (Project for Excellence in Journalism 2008).

Significantly, the literature on the hiring and retention of minorities into U.S. newsrooms suggests that the alleged neutrality of professional journalism is not perceived as such by minority reporters. On the contrary, the mainstream newsroom seems to generate frustration among minority journalists. Their frustration would explain why so many of them quit the newsroom, which, in turn, is commonly cited as an impediment to have newsrooms that better represent the country's racial and ethnic composition (e.g., ASNE 2003, Lehrman 2005, McGill 1999). Thus, while racial and ethnic minorities composed $34 \%$ of the total U.S. population in 2007, they accounted for only $13.5 \%$ of the workforce in newspapers, $6.2 \%$ in radio, and 21.5\% in television (ASNE 2008; Papper 2007). ${ }^{3}$

The industry recognizes that minorities face a "[1]ack of professional challenge and limited opportunities for advancement" in the mainstream newsroom (ASNE 2003). Critics, however, suggest that the dissatisfaction of minority professionals is also related to the limited scope for change in news practices and coverage (de Uriarte et al. 2003; Kelley \& Mills 2003; Mellinger 2003). Wilson (1991), for example, argues that black journalists are confronted with the paradox of either writing "Black' stories" or attaining professional success. Similarly, in his newsroom ethnography, Gans $(1980,194)$ observed that black journalists would leave the newsroom because "they could neither persuade editors that news about the black community was newsworthy nor could they find anyone with whom to discuss their interests in the culture and politics of the black community." For lowincome black reporters working at magazines the situation was even worse because "they 
could not conform to the upper-middle class ambience" (Gans 1980, 348). In these accounts, minority journalists bring into the newsroom what Benson (2005) calls "skindeep" diversity. In terms of "ideological diversity," in turn, their influence is fundamentally constrained (Benson 2005).

Professionalism, summarizes Glasser (1992b, 134), "implies standardization and homogeneity; it accounts not for differences among journalists but for what journalists have in common." As a result, "it should surprise no one that a defense of the latter can be construed as an assault on the former" (p. 134). The norms of professionalism, thus, may allow some minority journalists to be part of the newsroom and some minority communities to become target audiences. However, the professional journalist is expected to leave particular interests aside, regardless of his or her own cultural identity and of cultural differences within the audience.

Liberal resistance to state intervention. U.S. media's capacity to host diversity is further weakened by its relative aversion to state intervention. In fact the U.S. system's limited space for state regulations brings it closer to the liberal ideal than any other system (Hallin and Mancini 2004). Under the banner of the First Amendment, the press is seen as the guardian of free speech against the state. Thus, measures to intervene in media markets by strengthening public media, subsidizing minority media, or limiting media ownership generally fall outside common notions of what freedom of speech permits.

However, the view of the First Amendment in which "the state was the natural enemy of freedom" is misleading (Fiss 1996, 2) or at least contested. Some authors argue that it is precisely the need to assure the conditions for free speech that justifies state intervention (e.g., Baker 2002; Fiss 1996; Glasser \& Gunther 2005). For them, the freedom of speech that democracy needs does not guarantee each citizen's freedom to speak. Rather, freedom of speech is meant to protect citizens' freedom to hear the widest possible range of perspectives. Understood in this way, freedom of speech should secure actual diversity of speech, including the diversity of voices associated with culturally diverse social groups.

In conclusion, the U.S. media system is a rather hostile environment for cultural diversity. Its market structure marginalizes minority media as well as minority perspectives within the mainstream media. By definition, minority outlets are alternative publications that disrupt the monopoly that mainstream newspapers tend to have in most metropolitan areas. In addition, to the extent that they advance the interests of specific social groups, minority media contradict professional journalism's tenets of political detachment and neutrality. A high degree of professionalism among media workers and a strong resistance to state intervention further contribute to standardization within the liberal media system. These attributes are also related to a structural bias in favor of dominant social interests.

\section{Media's Corporate Formula to Make Diversity Compatible}

The forces toward standardization of media practices and content homogeneity in the U.S. media system beg the question of what U.S. journalism means when it claims to endorse cultural diversity. In other words, what kind of diversity is adopted in U.S. news media? To answer this question this section analyzes the discourse that has dominated discussions about cultural diversity in U.S. journalism during the last four decades.

Calls for diversity in U.S. journalism are commonly traced back to the late 1960s. In 1967, after some of the worst urban riots in the history of the United States, a National Advisory Commission on Civil Disorders was asked to investigate the social uproar, its causes, and ways to prevent something similar from happening in the future. The report by the Commission - known as the Kerner Report—included a special section on the mass 
media. While attributing the riots to the prevalence of white racism in society, the Commission found that the media had covered these specific events poorly and had neglected the life conditions of African Americans in general. Basically, the Commission established that there had been an "imbalance between reality and impression" (Report of Advisory Commission 1968, 202).

The Kerner Commission translated what it considered to be a problematic mismatch between reality and media portrayal into a lack of accuracy and professionalism:

We suggest that the main failure of the media last summer was that the totality of its coverage was not as representative as it should have been to be accurate. We believe that to live up to their own professional standards, the media simply must exercise a higher degree of care and a greater level of sophistication than the one they have yet shown in this area-higher, perhaps than the level acceptable with other stories (1968, 202-3).

At the same time that the Commission argued for the strengthening of journalists' professionalism and accuracy, it accused them of reporting and writing "from the standpoint of a white man's world" (p. 203) The U.S. mainstream press, it stated, "repeatedly, if unconsciously, reflects the biases, the paternalism, the indifference of white America" (p. 203). Among other things, the Commission recommended that the media pay more attention and resources to the coverage of racial issues and recruit and promote more African American journalists (who, by then, constituted less than 5\% of the workforce in U.S. newsrooms). The Commission further advised the creation of a non-profit and privately-funded organization to prepare journalists for the coverage of urban affairs; help recruit and train African American journalists; and support continuing research on the media's performance.

Essentially, the Kerner Commission criticized the insufficient professionalism and the ethnocentrism of mainstream media, as if there was no problematic connection between the two. In this way, the Commission set forth a central tension in current U.S. journalism's efforts for diversity: Is diversity a matter of accuracy and a means to strengthen professionalism and the commercial success of a news medium? Or is diversity fundamentally at odds with the professional and commercial model of journalism and thus a justification for change?

Privileging the first approach over the latter, the industry welcomed the Kerner Commission's recommendation on recruiting more minority journalists as a way to enhance news accuracy. In 1978, the American Association of Newspaper Editors (ASNE) adopted "newsroom parity" as one of the association's key goals and set the year 2000 as its deadline for achieving complete parity - that is, a perfect match between the composition of newsrooms and the demographics of the communities they cover. The "mathematics of diversity" (McGill 1999) became an "obsession" in the newspaper industry (McGowan 2001). However, it has also been a source of frustration: In 1998, the ASNE had to postpone its goal to 2025 , a date it may probably have to push back again.

The ASNE's diversity mission statement reads:

To cover communities fully, to carry out their role in a democracy, and to succeed in the marketplace, the nation's newsrooms must reflect the racial diversity of American society by 2025 or sooner. At a minimum, all newspapers should employ journalists of color and every newspaper should reflect the diversity of its community. 
The newsroom must be a place in which all employees contribute their full potential, regardless of race, ethnicity, color, age, gender, sexual orientation, physical ability or other defining characteristic (ASNE 1998). ASNE's parity goal has become a model throughout the industry. Broadcasting, magazine, and online associations have advanced similar targets and the different associations of minority journalists have supported these efforts. While some complain that the ASNE is moving too slowly, nearly everyone agrees that it is going in the right direction. Thus, the ASNE's mission statement can be read as the formula with which U.S. professional journalism in general has come to interpret and address cultural diversity.

Despite its general acceptance, three problematic issues are worth noting in the ASNE's mission statement. First, the ASNE statement presents diversity as a condition for professionalism. Translated into accuracy —into a tool to "reflect" the communitydiversity is supposed to contribute to professional objectivity. For example, a well-known diversity initiative in the newspaper industry is a training program for journalists called "Time-Out for Diversity and Accuracy." Organized by the ASNE and the Associated Press Managing Editors, the program defines "diversity not as a value that is apart from our core journalistic values but as part of the core" (ASNE 1999). In this way, the initiative is aimed at strengthening professional norms, not at challenging them.

The second paragraph of the ASNE's diversity mission statement is even more remarkable in its effort to make diversity compatible with professionalism. It suggests that the diverse members of the newsroom should be expected to perform as if there was no diversity. This expectation is clearly grounded in the guiding principles of the "professional communicator:" To the extent that reporters are mere transmitters of information, free from personal biases and other interests, their "defining characteristics," as the ASNE itself calls them, become inconsequential. It is important to notice the paradox here: ASNE claims that newsrooms must be diverse and it states, at the same time, that diversity should not significantly affect news coverage. Confronted with this paradox, black journalists ask themselves: "Am I a journalist who happens to be Black, or am I a Black journalist?" (Wilson 2000, 97), a question that seems equally applicable to Latinas/os, AsianAmericans, homosexuals, and other minority groups working in the mainstream media.

Finally, the ASNE statement points to diversity's marketplace appeal. Diversity, in the ASNE view, has to do with the industry's future economic survival. As the title of one of the panels in the 1999 ASNE Convention put it, taking diversity into account is responding to the "Economic Imperatives of Changing Audiences." Or, as Mark Willesone of the panelists and at the time CEO of the Times Mirror Corporation - told his colleagues, newspapers' efforts to reach diverse readers are not only morally, but also economically driven. Willes explained that his company's diversity measures had significantly improved the papers' journalistic quality. "We're also convinced that once we match the marketing efforts to go with these editorial efforts, we can grow our circulation across Times Mirror by tens of thousands, perhaps even hundreds of thousands. In our mind, that's the power of diversity" (Willes 1999). Not only for Times Mirror, but also for the other ASNE members, minorities have become attractive target markets. These "emerging" audiences seem to be a key solution against the declining numbers of newspaper readers. ${ }^{4}$ More than a matter of including historically ignored segments of the population, then, questions of diversity have been treated as questions of adapting to the changing consumer demand. 
The same economic logic that underlies the diversification of newsrooms drives media corporations to get into the foreign-language market. Producing news for nonEnglish speaking readers makes sense journalistically because "newspapers and journalists [have] an obligation to serve all the community," explained a second panelist in the 1999 ASNE Convention, the then publisher of the San Jose Mercury News, Jay Harris (1999). However, corporations take this obligation seriously only when ethnic audiences reach a "critical mass" (Project for Excellence in Journalism 2006). For example, while Harris himself was involved in the creation of a Vietnamese-language weekly - a unique initiative for media corporations across the U.S. - the project was only possible because it was based in San José, California, the city with the largest Vietnamese population outside Vietnam. As Shoemaker, Reese, and Danielson (1985) observed with respect to the media targeted at Latinas/os in Texas more than two decades ago,

Both social responsibility and market economic forces influence mass media content, with media owners balancing their desire to stay in business with the needs of the community. Yet the social responsibility forces in favor of media attention toward Texas Hispanics as an ethnic group which may have unique needs of information may be counterbalanced by the market economy forces which show that Texas Hispanics as a group have lower incomes than Anglos ... and are probably therefore a less attractive target for advertisers (p. 61).

Twenty-three years later social responsibility has converged with the "market economic forces." The attractiveness that Latinas/os have acquired for advertisers, in Texas and elsewhere in the U.S. (Dávila 2001; Gómez-Peña 1996), has generated an explosion of Spanish-language publications (Awad 2008). Only between 2002 and 2004, companies traditionally focused on the English market-including Cox, Knight Ridder, Tribune, Gannett, Hearst, and Freedom Communications-launched 81 Spanish newspapers (Whisler 2006). As stated in the 2004 report on The State of the News Media, "as the Hispanic population has grown in size and buying power a trend seems to be developing wherein large non-Hispanic companies are looking to tap into the Spanishspeaking market" (Project for Excellence in Journalism 2004).

\section{The Managerial Turn: From Diversity to Ornament}

As explained earlier, corporate media in the U.S. have not been alone in making diversity compatible with the demands of commercialism and professionalism. Together with other business organizations, they have endorsed the managerial approach to cultural diversity. Note, for example, the resemblance between the ASNE diversity mission statement and the diversity management philosophy advanced by diversity management expert Roosevelt Thomas (1990, 109):

The correct question today is not 'How are we doing on race relations?' or 'Are we promoting enough minority people and women?' but rather 'given the diverse workforce I've got, does it work as smoothly, is morale as high, as if every person in the company was the same sex, and race and nationality?' Most answers will be 'Well, no, of course not!' But why shouldn't it be, 'You bet!'?

Because the diversity management approach began as a model for managing human resources, its most obvious translation to the media industry centers on newsroom employment. However, as discussed above, the creation of "ethnic" media follows the same logic. Not surprisingly, in a book called Redefining Diversity, Thomas himself has 
expanded the notion of diversity to "the entire spectrum of strategic issues that modern corporations face" (1996, 3-4), including the diversity of consumers.

The managerial approach to diversity corresponds to what Lugones and Price (1995) call "ornamental multiculturalism." Ornamental multiculturalism subverts diversity by ignoring its historical and structural underpinnings and reducing it to ornament. It celebrates the variety of food, music, art, and literature associated with cultural diversity, yet it accommodates them within a given political and economic system that remains unchallenged. "A society is culturally pluralistic in an ornamental sense when the many cultures are inactive in informing the personality, character, beliefs, and values of worker/citizens and the structure of the economic and political system" (Lugones \& Price 1995, 105).

U.S journalism's diversity measures are ornamental to the extent that minorities are invited into the newsroom, but are not given the opportunity to take an active role in the (re)definition of news making practices and values as well as of the news media's politicoeconomic structure more generally. "Invitations" of this kind are assimilationist in the sense that they aim "to bring formerly excluded groups into the mainstream" (Young, 1990, 164). Moreover, they perpetuate social inequalities because "assimilation always implies coming into the game after it has already begun, after the rules and standards have already been set, and having to prove oneself according to those rules and standards" $(1990,164)$.

Accordingly, in the case of journalism, the "diverse" reporters who actually remain in the professional newsroom are considered to be those better assimilated into the dominant culture (de Uriarte et al. 2003; Kelley \& Mills 2003; Wilson 1991). Furthermore, these reporters' presence in the newsroom does not guarantee diversity in news coverage. On the contrary, there is evidence of "an increasing ideological narrowing, de-politicization and trivialization of American news during the same period when employment of minorities and women has increased" (Benson 2005, 9).

Ornamental multiculturalism uncritically upholds the dominant procedures and norms of the institutions which, in turn, uphold the existing social order. Its opponents instead propose a "critical" kind of multiculturalism (e.g., Chicago Cultural Studies Group 1992; Estrada \& McLaren 1993; Giroux 1993, Turner 1993). Critical multiculturalism criticizes "the ideological apparatuses that distribute power and resources unevenly among the different constituencies of a multicultural society" (Palumbo-Liu 1995, 2). In order to translate this critical approach to questions of journalism and cultural diversity then, it is necessary to acknowledge two key issues that ornamental multiculturalism neglects: the presence of structural inequality in multicultural societies and the ideological role played by the news media.

For ornamental multiculturalism, multiculturalism is basically a descriptive term, used to typify a society where multiple cultures co-exist. From this perspective, the justification for bringing diversity into the media is simple: In a society composed by multiple cultures, the media should reflect that diversity both in workforce and in news coverage. This is precisely the kind of responsibility assigned to journalism within the liberal media system: Politically balanced and detached news should accurately reflect reality.

For critical multiculturalism, in contrast, multiculturalism has above all a normative dimension. This means that critical multiculturalism does not simply account for the existence of culturally diverse groups, but it also recognizes unequal power relationships among these groups and, furthermore, it is committed to the eradication of those inequalities. More specifically, critical multiculturalism aims at structural changes to ensure 
that the needs of minority groups are equitably addressed. Aware that "needs are conceptualized in political struggle over who gets to define whose needs for what purpose" (Young 1998, 59), critical multiculturalism pays special attention to the discursive practices and institutions through which certain needs are articulated and recognized as valid. In doing this, critical multiculturalism must necessarily pay attention to journalism. From a critical perspective, the role of the news media is not to reflect a state of affairs (such a role would presuppose the existence of ideologically-free media). Rather, the media have to generate discursive spaces for more equalitarian dialogue among diverse social perspectives, thus contributing to the existence of more equal relations among culturally diverse groups.

\section{Conclusion}

As processes of media liberalization accompany discussions about immigration and multiculturalism in Western societies, the question of how to address cultural diversity in the media gains growing importance. This paper has argued that the answer to this question must differentiate between normative and economic motives. Moreover, the paper argues that normative motives must be prioritized over economic ones by adopting an interventionist as opposed to a laissez-faire approach to cultural diversity.

The laissez-faire approach operates ornamentally. Ornamental policies are not a weak kind of critical multiculturalism or a first or shy step in the right direction. Policies that manage certain aspects of culture to support existing institutions and serve the interests of those who are already in power, are a force against critical multiculturalism and, thus, against social justice. This means that the kind of media diversity that democracy demands must be distinguished from the kind of media diversity that serves media's commercial interests. As discussed with respect to the U.S., the uncritical celebration of the apparent correspondence of democratic and business interests reduces diversity to a business asset. The result strengthens the existing structure of media production, but does not secure a wider diversity of voices and social perspectives in the media.

In Europe, laissez-faire initiatives to bring diversity into the news media are relatively recent. However, there is already some evidence that their impact may point in the same direction as in the United States. Particularly in reference to British and Dutch public broadcasting, for example, Leurdijk (2006) explains that minority programs are being replaced by "cross-cultural" programs, tailored to the general audience and designed according to "the same logic of prime-time programming" (p. 42). The result offers "less space for niche tastes, preferences, subjects or angles that are more difficult to digest. It favours popular genres and young urban audiences at the cost of information and commercially less interesting audiences, such as first-generation immigrants" (p. 42). Likewise, based on an analysis of the Prix Europa Iris award for multicultural television, Horsti (2008) concludes that European media have recognized minority groups, but have failed to effectively include them in society. In her view, "journalistic practice could prompt and orchestrate debates rather than present consumable differences for the majority audiences" (p. 24).

Furthermore, an analysis of the European situation today must pay special attention to the socio-political context within which diversity in journalism is being discussed and implemented. Significantly, current initiatives to diversify European newsrooms, make journalists more sensitive and attentive to cultural differences, and address diverse audiences coincide with strong "calls contra diversity" throughout large parts of the continent (Vertovec \& Wessendorf 2005, 13). Accompanied by new and more restrictive 
policies towards immigrants, these calls have fueled discussions about the "end of multiculturalism" (Fekete 2004, 21; see also Joppke 2004) and "a shift to neoassimilationism" (Kofman 2005, 455; see also Grillo 2007). Thus, an assessment of diversity initiatives in the media (and elsewhere) must necessarily take into account the extent to which these initiatives support-or counter-neo-assimilationist agendas. The EBU Diversity Toolkit's helps illustrate this point. The introduction to the chapter on "Managing Diversity" explains: "The 'D' word [i.e., diversity] is one that is beginning to take a negative connotation. Why not see it as a chance to be innovative, to welcome new ideas, new angles, and in so doing increase our audiences? This is the moment to branch out, expand, vary our programmes and broaden our horizons" (A Diversity Toolkit 2008, 89). This way of dealing with cultural diversity is problematic from the perspective of critical multiculturalism. A critical approach aims at challenging diversity's negative connotation, not at adapting to it by making diversity management-friendly.

In sum, diversity in journalism must be defined and implemented according to democratic, not to business principles. Assuming a coincidence between the two may be detrimental to social inclusion. Considerations of whether diversity is profitable for the news media industry should lead not to strategies to manage diversity, but to interventions on the market in order to secure the kind of diversity that social justice demands. 


\section{References}

A Diversity Toolkit: For factual programmes in public service television. 2007. <http://fra.europa.eu/fra/material/pub/general/media-toolkit-documentation_en.pdf> Retrieved September 22, 2008

American Society of Newspaper Editors (ASNE). 1998. ASNE sets new vision for newsroom diversity beyond 2000. ASNE News Release. <http://www.asne.org/index.cfm?id=1400> Retrieved November 28, 2005.

American Society of Newspaper Editors (ASNE). 1999. National Time-Out for Diversity and Accuracy A Report from APME's Diversity Committee <http://www.asne.org/kiosk/diversity/1999timeout/> Retrieved January 16, 2006.

American Society of Newspaper Editors (ASNE). 2003. What the ASNE Retention Study Said. <http://www.asne.org/index.cfm?id=4876> Retrieved June 10, 2008.

American Society of Newspaper Editors (ASNE). 2008. Newsrooms shrink; minority percentage increases slightly. ASNE News Release. <http://www.asne.org/files/08Census.pdf> Retrieved June 10, 2008.

Awad, Isabel. 2008. What does it take for a newspaper to be Latina/o? A participatory definition of ethnic media. In N. Carpentier and B. De Cleen (eds.), Participation and Media Production. Critical Reflections on Content Creation, 83-96. Newcastle: Cambridge Scholars Publishing.

Baker, C. Edwin. 2002. Media, Markets, and Democracy. NY: Cambridge University Press.

Benson, Rodney. 2005. American Journalism and the Politics of Diversity. Media, Culture and Society 27, 1, 5-20.

Bogart, Leo. 1991. Preserving the press. How Daily Newspapers Mobilized to Keep their Readers. New York: Columbia University Press.

Brants, Kees and Philip van Praag. 2006. Signs of Media Logic: Half a Century of Political Communication in the Netherlands. Javnost - The Public 13, 1, 25-40.

Brussels Debate Highlights the Business Case for Intercultural Dialogue in the Workplace. 2008 (June 4).

<http://www.interculturaldialogue2008.eu/fileadmin/downloads/documents/600press\%20releases/080604_BDE4_3_DTSK.pdf > Retrieved September 23, 2008.

Carey, James W. 1969. The Communications Revolution and the Professional Communicator. Sociological Review Monograph 13, 23-38.

Centre for Strategy \& Evaluation Services. 2003. Indicators to Measure the Costs and Benefits of Diversity Policies in Companies $<$ http://ec.europa.eu/employment_social/fundamental_rights/pdf/arc/stud/cbfullrep_ en.pdf $>$ Retrieved June 10, 2008.

Chicago Cultural Studies Group. 1992. Critical Multiculturalism. Critical Inquiry 18, 530555.

Dávila, Arlene. 2001. Latinos Inc. The Marketing and Making of the People. Berkeley: University of California Press.

De Uriarte, Mercedes, L. Cristina Bodinger-de Uriarte and José L. Benavides. 2003. Diversity Disconnects. <http://journalism.utexas.edu/facstaff/deuriarte/index.htm> Retrieved June 4, 2006.

Estrada, Kelly and Peter McLaren. 1993. A Dialogue on Multiculturalism and Democratic Culture. Educational Researcher 22, 3, 27-33. 
European Broadcasting Union (EBU). 2008. Cultural Diversity. <http://www.ebu.ch/en/union/under_banners/CulturalDiversity_2008.php> Retrieved October 10, 2008.

Fekete, Liz. 2004. Anti-Muslim Racism and the European Security State. Race \& Class 46, 1, 3-29.

Fishman, Mark. 1980. Manufacturing the News. Austin: University of Texas Press.

Fiss, Owen M. 1996. The Irony of Free Speech. Cambridge, MA: Harvard University Press. Gans, Herbert J. 1980. Deciding What's News. A Study of CBS Evening News, NBC Nightly News, Newsweek and Time. New York: Vintage.

Giroux, Henry A. 1993. The Politics of Insurgent Multiculturalism in the Era of the Los Angeles Uprising. The Journal of the Midwest Modern Language Association 26, 1, 12-30.

Glasser, Theodore L. 1984. Competition and Diversity among Radio Formats: Legal and Structural Issues. Journal of Broadcasting 28, 2, 127-142.

Glasser, Theodore L. 1992a. Objectivity and News Bias. In E. D. Cohen (ed.), Philosophical Issues in Journalism, 176-183. New York: Oxford University Press.

Glasser, Theodore L. 1992b. Professionalism and the Derision of Diversity: The Case of the Education of Journalists. Journal of Communication 42, 2, 131-140.

Glasser, Theodore L. and Marc Gunther. 2005. The Legacy of Autonomy in American Journalism. In K. H. Jamieson and G. Overholser (eds.), Institutions of Democracy: The Press, pp. 384-399. New York: Oxford University Press.

Gómez-Peña, Guillermo. 1996. The Multicultural Paradigm: An Open Letter to the National Arts Community. In G. Mosquera (ed.), Beyond the Fantastic, 181-193. Cambridge, MA: MIT Press.

Grillo, Ralph. 2007. An excess of alterity? Debating difference in a multicultural society. Ethnic and Racial Studies 30, 6, 979-998.

Hallin, Daniel C. (1985). The American News Media: A Critical Theory Perspective. In J. M. Forester (ed.), Critical Theory and Public Life, 121-146. Cambridge, MA: MIT Press.

Hallin, Daniel C., and Paolo Mancini. 2004. Comparing Media Systems. Three Models of Media and Politics. Cambridge: Cambridge University Press.

Harris, Jay. 1999. Presentation at ASNE panel "It's your future: Economic imperatives of changing audiences".

<http://www.asne.org/kiosk/archive/convention/conv99/economicimperatives.htm> Retrieved January 26, 2006.

Horsti, Karina. 2008. Anti-racist and multicultural discourses in European public broadcasting. Paper presented at International Communication Association, at Montreal, Canada.

Iosifides, Petros. 1999. Diversity versus concentration in the deregulated mass media domain. Journalism \& Mass Communication Quarterly 76, 1, 152-162.

Joppke, Christian. 2004. The retreat of multiculturalism in the liberal state: theory and policy. The British Journal of Sociology, 55, 237-257.

Kelley, Ronald B. and Dean Mills. 2003. Covering the Undercovered. The Evolution of Diversity in the News. In F. Cropp, C. M. Frisby and D. Mills (eds.), Journalism Across Cultures, 3-22. Ames, IA: Iowa State Press.

Kofman, Eleonore. 2005. Citizenship, Migration and the Reassertion of National Identity. Citizenship Studies, 9, 5, 453-467. 
Lehrman, Sally. 2005. News in a New America. Miami, Fla: John S. and James L. Knight Foundation. <http://www.knightfoundation.org/global/pdf/KF_News-in-a-NewAmerica_web.pdf > Retrieved June 10, 2008.

Leurdijk, Andra. 2006. In Search of Common Ground. European Journal of Communication 9, 1, 25-46.

Lorbiecki, Anna. 2001. Changing Views on Diversity Management: The Rise of the Learning Perspective and the Need to Recognize Social and Political Contradictions. Management Learning 32, 3, 345-361.

Lugones, María and Joshua Price. 1995. Dominant Culture: El Deseo por un Alma Pobre (The Desire for an Impoverished Soul). In D. A. Harris (ed.), Multiculturalism from the Margins, 103-127. Westport, CT: Bergin \& Garvey.

Making Progress in 2007. 2007. Equal Rights in Practice 8, 4-5. <http://ec.europa.eu/employment_social/fundamental_rights/pdf/pubst/news/nl8_07 _en.pdf> Retrieved October 20, 2007.

McGill, Lawrence T. 1999. Newsroom Diversity. Meeting the Challenge [electronic version]. Arlington, VA: Freedom Forum.

$<$ http://www.freedomforum.org/publications/diversity/meetingthechallenge/meeting thechallenge.pdf> Retrieved January 20, 2006.

McGowan, William. 2001. Coloring the News. How Political Correctness Has Corrupted American Journalism. San Francisco, CA: Encounter Books.

Mellinger, Gwyneth. 2003. Counting Color: Ambivalence and Contradiction in the American Society of Newspaper Editors' Discourse of Diversity. Journal of Communication Inquiry 27, 2, 129-151.

Palumbo-Liu, David. 1995. Introduction. In D. Palumbo-Lu (ed.), The Ethnic Canon: Histories, Institutions, and Interventions, 1-27. Minneapolis, MN: University of Minnesota Press.

Papper, Bob. 2007. Year of Extremes. Communicator, July/August, 24-28 < http://www.rtnda.org/media/pdfs/communicator/2007/julaug/2025_Survey_Communicator.pdf> Retrieved June 10, 2008.

Project for Excellence in Journalism. 2004. Spanish Language Press. In The State of the News Media 2004.

<http://www.stateofthenewsmedia.org/2004/narrative_ethnicalternative_spanishpres s.asp?media=9> Retrieved September 10, 2008.

Project for Excellence in Journalism. 2006. Ethnic Media Overview. In The State of the News Media 2006. <http://www.journalism.org/node/1480> Retrieved May 2, 2007.

Project for Excellence in Journalism. 2008. The Changing Newspaper Newsroom. In The State of the News Media 2008.

<http://www.stateofthenewsmedia.org/2008/narrative_special_newsroom.php?cat=2 \&media=13>. Retrieved September 26, 2008

Report of the National Advisory Commission on Civil Disorders. 1968. Washington: U.S. Government Printing Office.

Ruby, Robert \& Project for Excellence in Journalism. 2008. Public Attitudes. In The State of the News Media 2008.

<http://www.stateofthenewsmedia.org/2008/narrative_special_attitudes.php?cat=1\& media=13>. Retrieved September 26, 2008 
Shoemaker, Pamela, Stephen Reese and Wayne Danielson. 1985. Spanish-language Print Media Use as an Indicator of Acculturation. Journalism Quarterly 62, 4, 734-740, 762.

Siune, Karen. 1998. Introduction. Changing Media and Changing Society. In D. McQuail and K. Siune (eds.), Media Policy. Convergence, Concentration \& Commerce. London: Sage.

Siune, Karen and McQuail, Denis. 1986. Media Policy in Transition. In D. McQuail and K. Siune (eds.), New Media Politics: Comparative Perspectives in Western Europe, 111. London: Sage.

Soloski, John. 1989. News reporting and professionalism: some constraints on the reporting of the news. Media, Culture and Society 11, 207-228.

Stratton, Jon and Ien Ang. 1994. Multicultural imagined communities: cultural difference and national identity in Australia and the USA. Continuum: The Australian Journal of Media and Culture 8, 2, 125-158.

The Diversity Show. 2008a. Fritz Pleitgen keynoter at the Diversity Show. <http://www.diversityshow.nl/index.php?mact=News,cntnt01,detail,0\&cntnt01articl eid=5\&cntnt01 returnid=15\&hl=en_US $>$ Retrieved October 2, 2008.

The Diversity Show. 2008b. Plenary Sessions. <http://www.diversityshow.nl/index.php?page=dagprogramma\&hl=en_US> Retrieved October 2, 2008.

Thomas Jr., R. Roosevelt. 1990. From Affirmative Action to Affirming Diversity. Harvard Business Review March/April, 2, 107-117.

Thomas Jr., R. Roosevelt. 1991. Beyond Race and Gender. New York: Amacom.

Thomas Jr., R. Roosevelt. 1996. Redefining Diversity. New York: Amacom.

Tuchman, Gaye. 1978. Making News: A Study in the Construction of Reality. New York: The Free Press.

Turner, Terence. 1993. Anthropology and Multiculturalism: What is Anthropology That Multiculturalists Should Be Mindful of It? Cultural Anthropology 8, 4, 411-429.

Van Cuilenburg, Jan and McQuail, Denis. 2003. Media Policy Paradigm Shifts. Towards a New Communications Policy Paradigm. European Journal of Communication 18, 2, 181-207.

Vertovec, Steven and Wessendorf, Susanne. 2005 Migration and Cultural, Religious and Linguistic Diversity in Europe: An Overview of Issues and Trends. Working paper No. 18, Center of Migration Policy and Society (COMPAS), University of Oxford. <http://www.compas.ox.ac.uk/publications/Working\%20papers/Vertovec\%20Wesse ndorf\%20WP0518.pdf> Retrieved September 20, 2008.

Whisler, Kirk. 2006. 2005 Was a Pivotal Year for Hispanic Print. Hispanic Marketing 101 $4,1,2$.

Willes, Mark. 1999. Presentation at ASNE panel "It's your future: Economic imperatives of changing audiences".

<http://www.asne.org/kiosk/archive/convention/conv99/economicimperatives.htm> Retrieved January 26, 2006.

Wilson, Clint C. 1991. Black Journalists in Paradox: Historical Perspectives and Current Dilemmas. New York: Greenwood Press.

Wilson, Clint C. 2000. The Paradox of African American Journalists. In S. Cottle (ed.), Ethnic Minorities and the Media, 85-99. Philadelphia: Open University Press.

Wrench, John. 2005. Diversity management can be bad for you. Race Class 46, 3, 73-84. 
Young, Iris Marion. 1990. Justice and the Politics of Difference. Princeton: Princeton University Press.

Young, Iris Marion. 1998. Unruly Categories: A Critique of Nancy Fraser's Dual Systems Theory. In C. Willet (ed.), Theorizing Multiculturalism, 50-67. Malden, MA: Blackwell. 


\section{Notes:}

${ }^{1}$ Stratton and Ang (1994) use the distinction between "laissez-faire" and "interventionist" approaches to cultural diversity to characterize the U.S. and the Australian case. This distinction is also be helpful to compare the U.S. and European countries, particularly with respect to the media.

${ }^{2}$ For example, this is the case with Fox News, which has been widely criticized for its conservative partisanship. The arguments of both Fox News and its detractors reinforce the value ascribed to political neutrality. With slogans such as "We Report. You Decide" and "Fair and Balanced," Fox accuses other media of bias.

${ }^{3}$ Similar reasons may explain the under-representation of women in U.S. newsrooms. In 2007 , women composed $37.4 \%$ of the workforce in newspapers, $39.9 \%$ in TV news, and $24.4 \%$ in radio news. In supervising positions, these numbers are even lower for both women and minority journalists (ASNE 2008; Papper 2007).

${ }^{4}$ The decline in circulation of daily newspapers has been a main concern in the industry since the emergence of electronic media, especially television (see Bogart 1991). 